\title{
HERPETOLOGY OF TORTOLA; NOTES ON ANEGADA AND VIRGIN GORDA, BRITISH VIRGIN ISLANDS
}

\author{
Chapman Grant, Major U.S. Army
}

There are several theories advanced to explain the distribution of the flora and fauna of the West Indies. This is a problem for the Biologist, Botanist and Geologist to work out together. The superficial appearances are that land comnections existed with North America via the Bahamas; with Central America; with South America. How extensive these connections were in both time and space is conjecture. For that matter, the whole Caribbean Sea may have been land at one time. The solution of the problem can be helped by knowledge of the species of plants and animals that inhabit the islands. With this end in view, the writer visited Tortola from August 10th to 16 th, 1932 . The results were gratifying.

The most complete and accurate compilation of the herpetological fauna of this area is Barbour's "A List of Antillean Reptiles and Amphibians" Zoological, XI, No. 4, 1930. Therein are listed eight species from Tortola. The writer had the satisfaction of adding nine species to this list and one to Barbour's list of seven from Anegada. He also added four Cactaceae to Dr. Britton's list from Tortola, and added specimens and information on the herpetology of St. Thomas and St. John. The last was previously deseribed in this Journal, adding ten to Barbour's five listed species. The present trip produced another from St. John, making the total from that island sixteen. The writer's stay on Tortola was made pleasant and profitable by the hospitality of Commissioner Clarkson and the enthusiasm of $\mathrm{Mr}$. Fonseca.

The following annotated list is the result of the trip:

Bufo turpis Barbour

Found only on Virgin Gorda. The type, and seven specimens taken by Dr. Danforth of Mayaguiez in 1931 are the only specimens known.

Eleutherodactylus portoricensis Schmidt

Known locally as "bo-peep". Not listed by Barbour.

The discovery of this species on Tortola is of especial interest on account of the light it throws on frogs of the same name in Puerto Rico. The series of 44 from Tortola shows very little variation in 
color, pattern, size or voice. This strengthens the conviction that two or more species are included under this name in Puerto Rico. The Tortola specimens have a light gray back, white belly, no pattern or marking other than a dark canthus rostralis and occasionally orange on covered surface of thighs. The voice has no variations as on Puerto Rico. Their song is heard everywhere from afternoon throughout the night. They seem greatly to outnumber E. antillensis, judging from the volume of sound, as compared to the relatively uncommon "click-click-click" of the latter.

Specimens taken: Tortola, 44.

Late one evening while tacking up the channel between St. John and Thatch Island of Tortola, the "bo-peep" of E. portoricensis could be heard each time that the shores of St. John were neared. This adds a new record to the herpetological list of St. John.

\section{Eleutherodactylus antillensis (Reinhard \& Lütken)}

No local name. This species is confounded by the natives with E. portoricensis as a "bo-peep". Listed by Barbour. Uncommon, not found on adjacent islets. The voice, a "click-click-click" is identical to the Puerto Rico and St. John specimens. Color much darker; no terracotta or gray backs seen; one specimen had a violetpink back. The characteristic red eye, black eanthus rostralis and reticulated thighs present. The voice is seldom heard among the babel of "bo-peep" of $E$. portoricensis.

Specimens taken: Tortola, 6.

Note: The voice of another species, resembling that of E. gryllus was heard, but the frogs were not located.

\section{Leptodactylus albilabris (Günther)}

Known locally as "water frog". Listed by Barbour. Not found on any surrounding islets. Numerous; breeding. Voice same as elsewhere. Individuals average darker with more spotted throat than on Puerto Rico but much lighter than the St. Thomas and St. John forms which have a much more spotted throat. No large specimens seen as on Puerto Rico.

This frog has a throaty chuckling trill, apparently used during uncertainty as to threatening danger. It follows or precedes the song which is "creep", repeated many times. The "pink" mentioned by Stejneger is really a single note, often repeated and sounding like a sharp instrument being tapped on metal. Individuals seem to give this in different keys. There are other little notes that sound almost like a conversation.

Specimens taken: Tortola, 50. 


\section{Hemidactylus mabouia (Moreau de Jonnés)}

Locally shares the name of "wood slave" with the Giant Anolis. Listed by Barbour. This is the real $H$. mabouia and not the $H$. brookii Gray of Puerto Rico that long masqueraded under this name. None seen on buildings at night. Rare.

Specimens taken; Peter Island, 2. A small Alsophis antillensis taken at the same time and place disgorged an adult $H$. mabouia.

\section{Sphaerodactylus macrolepsis Günther}

Locally known as "cotton ginner". Listed by Barbour. Common. Found on most of the outlying islets. No red-head males taken or seen. This further strengthens the position of $S$. danforthi, which is similar, but has a proportion of red-head males. It has none of the characteristics of the distinct $S$. grandisquamis Stejneger of Puerto Rico.

Specimens taken: Tortola, 145; Peter Island, 1; Buck Island 13. Seen on Guana Island.

\section{Iguana iguana}

Known locally as "guana". Not listed by Barbour. Guana Island derives its name from this species. It is not used for food by the natives. Known only from Guana Island and Peter Island of the British Virgins. No specimens taken but one seen on Peter Island.

A previous report was made of taking iguanas on Water Island, St. Thomas. On this trip a specimen was taken on Hassell Island, St. Thomas, and one was seen in a grape arbor in the City of St. Thomas. They are said to be numerous at Botany Bay. An Alsophis antillensis taken on the beach of Water Island had eaten three baby iguanas, probably recently hatched. These were bright green, tail ringed brown, green and blue. The most noticeable mark is a white stripe from neck to elbow. Snout to vent $75 \mathrm{~mm}$; tail 190 $\mathrm{mm}$. A story prevalent among the natives, and seemingly true, is that the iguana will take refuge by diving into the sea where it will cling to the rocks. The eggs, to the number of 30 or more, are buried in beach sand. The tracks and mark of the dragging tail are a common sight on the beaches. Barbour lists Iguana rhinolopha Wiegmann and Iguana delicatissima Laurenti as the only species of this genus occurring in the West Indies.

I. rhinolopha has tubereles on the snout and $I$. delicatissima has 19-20 femoral pores. The Virgin Islands specimens have smooth 
snouts and only $13-15$ pores, placing them with $I$. iguana, which has 12-18 pores.

\section{Anolis chvieri Merrem.}

Possibly known locally as "wood slave". Listed by Barbour. None seen. Inasmuch as a distinct speeies A. roosevelti Grant is found on Culebra, the occurrence of this species on Tortola is doubtful. A giant Anolis on Tortola would probably be a distinct species.

\section{Anolis cristatellus Duméril \& Bibron}

Known locally as "man lizard", "doctor lizard" and "common lizard". Listed by Barbour. Very numerous. The green and red of the throat fan is constant here and not subject to the great variation seen on Puerto Rico. The tail fin on males from some of the islets is extremely high. One specimen from Guana Island has the fin rays as long as snout to posterior part of orbit, or $3^{1 / 2}$ times as high as tail is deep at that point, or $15 \mathrm{~mm}$. high. This is the highest fin I have ever seen.

Specimens taken: Tortola, 63; Peter Island, 10; Guana Island, 2; Fallen Jerusalem, 5; Anegada, 15 . Seen on all small islets visited.

\section{Anolis pulchellus Duméril \& Bibron}

Known locally as "snake lizard". Listed by Barbour. Numerous in grassy places. Apparently identical to the Puerto Rico specimens, except that on Puerto Rico this species is unique in having a crimson eenter to the red fan.

Specimens taken: Tortola 23; Peter Island 2; Guana Island 1. Anolis stratulus Cope

Innown locally as "salmon lizard". Listed by Barbour. Very numerous. Average much lighter colored with deeper orange fan than the Puerto Rico specimens; hence the dorsal marks are much more pronounced. When threatening fight, the males protrude a blood red tongue which at other times is pink.

Specimens taken: Tortola, 40; Peter Island, 2; Guana Island, 1. Seen on Fallen Jerusalem.

\section{Cyclura pinguis Barbour}

Known locally as "guana". Listed by Barbour as "excessively rare if not now gone". Now reported numerous on Anegada. Color notes from living specimens: Tongue and lining of mouth pink pupil vertical, iris dark brown but small, leaving the white of the 
eye so prominent as to appear to be a white iris. Above: face, sides of head, between eyes and lower jaw bulbs olive; strip across nostrils including the turtle-like rostral, postocular bulbs and "cape" reaching to shoulders, dark brown reticulated with black; thence to base of tail black reticulation more prominent, forming three black chevrons, points at erest; tail dull turquoise blue reticulated with black on basal third, thence brown; caudal crest turquoise. Below: dewlap and chest mahogany, fading to gray on belly and tail; occasional dark scales form patterns on undersides of legs and sides of body and especially on posterior aspect of thighs. The scales of back and sides are soft and granular, giving a leathery appearance and texture.

Specimens taken: Anegada, 2 young males. Snout to tip of tail $1,075 \mathrm{~mm}$; snout to vent $410 \mathrm{~mm}$. These are about two-thirds adult length and about one-third bullk.

\section{Ameiva exsul Cope}

Known locally as "ground lizard". Not listed by Barbour. Common in flat or sandy places on Tortola and adjacent keys. On Tortola this species is dark, loses its dorsal stripes early in life and does not have the reddish or lavender chin frequently seen elsewhere. It coincides exactly with the species on Puerto Rico in femoral pore count. There is a wider variation in anal plates, but not to a significant degree. Altogether, it is the least attractive representative of the species in the area. No large specimens were seen, probably due to the mongoose. Two large specimens from Buck Island were colored in the same drab fashion, but Guana Island, Peter Island and Anegada produced large, highly colored specimens, with prominent dorso-lateral stripes, reminiscent of similar ones on Culebra. One Peter Island specimen had particularly noticeable turquoise blue on the sides of head and neck. A color combination new to me. The bright colored speeimens had a lower pore count, but there were not enough taken to determine whether this was of any significance.

Specimens taken: Tortola, 34; Peter Island, 4; Buck Island, 2; Guana Island, 2; Anegada, 2. The specimens from Anegada are a new record from that Island.

\section{Amphisbaena fenestrata Cope}

Known locally as "ground worm". Not listed by Barbour. The specimens taken differ from $A$. fenestrata in having only one temporal scute instead of two, and 16 segments below the lateral line 
344 THE JOURNAL OF THE DLPARTIIENT OF AGRICULTURE OF P. k.

instead of 14. It may remain in this species pending further comparison. It is difficult to procure as "there is not a plow in Tortola". Specimens taken: Tortola, 5 .

\section{Mabuya semitaeniatus (Wiegmann)}

Known locally as "slippery back". Not listed by Barbour. Rare. The one specimen taken on Salt Island does not coincide in color or squamation with a series of 155 specimens from Culebra, Mona and Buck Island, of St. Thomas. It is still further removed from M. sloanii (Daudin) of Puerto Rico. It may remain as M. semitaeniatus pending comparison with more material.

Specimens taken: Salt Island, 1.

\section{Typhlops richardii Duméril \& Bibron}

Known locally as "ground snake". Not listed by Barbour. This species has the dark mahogany coloration and small size of T. rostellatus Stejneger, but lacks the white chin and tail markings. It is smaller than $T$. jamaicensis (Shaw), lacking the white caudal notch or ring and the light venter.

This species is reestablished pending a study of the material from this area, of which 225 specimens from Vieques, Culebra, Mona, St. John, St. Thomas, Caja de Muertos, Tortola and Puerto Rico are in my collection.

Found under a heap of bagasse at a rum mill, apparently preying upon small life, together with the Amphisbaena and the three species of frogs. Shed skins had the appearance of quills, not collapsing like ordinary snake skins.

Specimens taken: Tortola, 32.

\section{Epicrates sp.}

Species to be deseribed later.

Known locally as "night snake". Not listed by Barbour. Said to attain five feet or more in length. Inhabits rocky cliffs on Tortola and Guana Island. It was a great surprise to find a boa so far east of the eastern record of this family, Epicrates inornatus (Reinhardt) of Puerto Rico, and greatly lessening the gap to Dominica and Constrictor orophias (L), the northern limit of the family in the West Indies.

Specimens taken: Tortola, 1. 


\section{Alsophis antillensis (Schlegel)}

No local name other than "snake". Not listed by Barbour from Tortola. Listed from Virgin Gorda.

This snake varies considerably on the different islets. A specimen from Salt Island being typical of a large series from Culebra. Two from Peter Island are uniquely marked; four scales of the fourth, fifth and sixth rows forming a white spot with a dark border. There is a checkerboard pattern on the neck. The throat of all specimens is straw yellow in life. One specimen from Peter Island disgorged an adult Hemidactylus mabouia. A specimen from Water Island, St. Thomas, contained three young Iguana iguana. This snake is most readily found at early morning along the beaches. It is seldom met with after 10:00 a. m. Reported very rare on Tortola but said to occur on all the islets around.

Specimens taken: Salt Island, 1; Peter Island, 2.

\section{Dromicus exiguus Cope}

No local name for this species which is apparently locally considered to be the young of Alsophis. Not listed by Barbour. Frequently met with by persons gardening or eultivating. Two specimens reported to have been found "torpid" in the "Winter" in the eracks of an old wall which was being demolished. Apparently identical to St. Thomas specimens.

Specimens taken: Tortola; 2.

\section{Testudo tabulata}

Known locally as "land turtle". Not listed by Barbour. According to inhabitants, occasionally met with in the "bush" on Tortola but "none seen within two years". The certainty with which natives state that none occurs on any of the outlying islets, lends strength to their statements of its occurrence on Tortola. Another check is the immediate answer that there are no fresh water turtles.

Excluding Testudo tabulata, the above list adds 9 species to Tortola and its adjacent islets that are new to Barbour's list of 8 and gives the island a population of 17 species.

The most important finds were the discovery of the boa and that E. portoricensis is not confined to Puerto Rico.

The cactaceae listed by Britton from Tortola are: Cephalocereus Royeni; Hylocereus undatus; Selenicereus grandiroris; Cactus intortus; Neomamimilaria nivosa; Opuntia repens; $O$. antillana; $O$. 
346 THE JOURNAL OF THE DEPARTMENT OF AGRICULTURE OF P. R.

rubescens. Of these, H. undatus was not found, but Hylocereus trigonus (Haw.) Stafford was found to be abundant and is added to the flora of the island together with Opuntia Dillenii (Ker-Gawl) Haw.; Opuntia triacantha (Willd.) Sweet; Lemaireocereus hystrix (Haw.) Britton \& Rose, all of which are abundant.

\section{Explanation of Plates}

Plate XL. Cyclura pinguis. Note the whites of the eyes, large nostrils and muscular bulb of lower jaw.

Plate XLI. Same; note throat fan and absence of rostral spines. Plate XLII. Same; note lateral fold, smooth snout and throat fan.

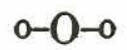

